\title{
Dilema Etis Konsultan Pajak dalam Tax Planning: Studi Fenomenologi
}

\author{
Anak Agung Istri Pradnyarani Dewi a *, Made Sudarma ${ }^{\text {a }}$, Zaki Baridwan a \\ ${ }^{a}$ Universitas Brawijaya, Malang, Jawa Timur, Indonesia
}

INFORMASI ARTIKEL

Article history:

Dikirim tanggal: 02 Agustus 2018

Revisi pertama tanggal: 15 Agustus 2018

Diterima tanggal: 20 Agustus 2018

Tersedia online tanggal: 04 September 2018

Keywords: dilema etis, konsultan pajak, tax planning, wajib pajak

\author{
ABSTRACT
}

Tax consultant helps the taxpayers taxation. Taxpayer requesting tax consultant do tax planning towards illegal. Tax consultant must adhere to the rules. This poses dilemma. This study was conducted to determine and observe how the tax consulting experience in facing dilemma when making tax planning using the approach of transcendental phenomenology. The results of this study have some form of dilemma is a dilemma due to unclear regulations and sympathy to the client. Through the experience of a tax consultant, this dilemma can be overcome with some consideration is to deepen awareness of rules and build awareness of the taxpayer.

\section{INTISARI}

Konsultan pajak berfungsi membantu wajib pajak dalam urusan perpajakan. Wajib pajak cenderung meminta konsultan pajak melakukan tax planning ke arah illegal. Konsultan pajak harus memegang teguh aturan. Hal ini menimbulkan dilema. Penelitian ini dilakukan untuk mengetahui serta mendalami bagaimana pengalaman konsultan pajak dalam menghadapi dilema saat melakukan tax planning dengan menggunakan pendekatan fenomenologi transcendental. Hasil dari penelitian ini konsultan pajak mempunyai beberapa bentuk dilema, antara lain: dilema akibat ketidakjelasan peraturan yang berlaku dan rasa simpati terhadap klien. Melalui pengalaman konsultan pajak, dilema tersebut dapat diatasi dengan beberapa pertimbangan yaitu kesadaran untuk mendalami peraturan dan "siasat" untuk membangun kesadaran wajib pajak.

2018 FIA UB. All rights reserved.

\section{Pendahuluan}

Pajak merupakan salah satu aspek penting dalam keberlangsungan jalannya pemerintahan tidak hanya dalam dunia ekonomi saja namun bisa berperan dalam segala bidang. Mengapa pajak dianggap penting? Seperti yang kita ketahui pajak merupakan penyumbang keuangan negara yang terbesar, dengan adanya pemungutan pajak pemasukan suatu negara akan meningkat. Pemerintah Indonesia setiap tahunnya menetapkan target penerimaan pajak, walaupun terkadang target yang di tetapkan oleh pemerintah tersebut tidak tercapai seperti halnya pada tahun 2017 dimana target pajak hanya tercapai $89,4 \%$ dari target yang telah di tetapkan (Setyowati, 2018). Penerimaan pajak yang belum mencapai target tersebut disebabkan oleh banyak faktor, salah satunya adalah adanya kendala dari wajib pajak terutama dalam hal kesadaran wajib

* Corresponding author. Tel.: +62-858-5781-1003; e-mail: aipradnyarani@gmail.com 
pajak untuk patuh dalam kewajiban pajaknya (tax compliance). Kurangnya kesadaran dapat dikarenakan kurangnya pemahaman wajib pajak dan juga karena pemahaman wajib pajak menganggap pajak itu hanyalah beban. Wajib pajak khususnya wajib pajak badan, memaknai pajak penghasilan akan mengurangi bagian laba yang seharusnya dapat dimanfaatkan di perusahaannya (Khoesanto, 2013). Oleh sebab itu untuk menekan biaya pajak penghasilannya, wajib pajak badan dapat melakukan salah satu upaya, yaitu untuk meminimalkan pembayaran pajaknya yang terhutang dengan membuat perencanaan pajak (Tax Planning).

Fenomena saat ini, Tax planning telah banyak dilakukan oleh wajib pajak badan. Tax planning sendiri berdampak pada kurang tercapainya target pajak yang ditetapkan negara. Tax planning secara illegal dapat dilakukan dengan menyembunyikan data sesuai fakta secara disengaja, ataupun dengan sama sekali tidak membayarkan pajaknya. Sedangkan tax planning secara legal dilakukan wajib pajak dengan memanfaatkan halhal yang tidak diatur atau celah yang ada dalam undangundang dan peraturan perpajakan (loopholes) (Darmayasa \& Hardika, 2011). Peraturan pajak yang sangat rumit membuat wajib pajak membutuhkan seorang tax planner. Dalam hal perpajakan, wajib pajak badan kerap membutuhkan bantuan konsultan pajak untuk membantunya membuat perencanaan pajak perusahaannya. Konsultan pajak adalah orang yang memberikan jasa profesional kepada para wajib pajak dalam memenuhi kewajiban perpajakannya sesuai dengan aturan perundang-undangan. Konsultan pajak mempunyai kode etik yang harus ditaati. Kode etik dimiliki untuk menjaga independensi, profesionalisme, dan integritas konsultan pajak dalam menjalankan profesinya. Namun disisi lain, tidak dapat dipungkiri bahwa keahlian yang dimiliki oleh konsultan pajak juga dapat disalahgunakan untuk membantu wajib pajaknya dalam memanfaatkan peluang untuk melakukan ketidakpatuhan (Erard, 1993).

Devos (2012) menyatakan bahwa adanya hubungan yang spesifik antara tujuan wajib pajak membutuhkan konsultan pajak dan perilaku kepatuhan wajib pajak. Wajib pajak memggunakan jasa konsultan pajak dengan sejumlah alasan salah satunya untuk meminimalkan kewajiban pajak yang harus dibayar dengan membuat suatu perencanaan pajak. Frecknall-Hughes \& Kirchler (2015) berpendapat bahwa konsultan pajak memiliki salah satu jasa yaitu jasa perencanaan pajak yang cenderung mengarah kepada tindakan meminimalkan beban pajak secara agresif. Hal tersebut tidak dapat dihindar karena konsultan pajak memiliki suatu keterampilan dalam menyelesaikan kewajiban pajak wajib pajak sekaligus memahami motivasi, serta keinginan wajib pajak ketika meminta jasa konsultan pajak untuk menyelesaikan tanggung jawab sebagai wajib pajak (Mangoting, 2017). Dalam fenomena ini, konsultan pajak kerap mengalami kondisi dilema. Kondisi dilema tidak lain karena adanya kode etik yang harus ditaati dan faktor-faktor yang dihadapi seperti halnya menggunakan celah dalam pembuatan tax planning, kelangsungan bisnis, kepedulian terhadap negara atau wajib pajak itu sendiri ataupun faktor dari imbalan yang diberikan. Konsultan pajak lebih memiliki sensitifitas etika yang tinggi dibanding profesi lainnya (Massie, 2017).

Dilema etis konsultan pajak, menghadapkan konsultan pajak untuk membuat suatu pertimbangan yang etis dalam membuat keputusan. Keputusan yang diambil dapat tetap pada prinsip profesionalitasnya atau bertentangan dengan prinsipnya. Disisi lain, imbalan dan kelangsungan bisnis pun kerap menjadi suatu faktor dalam mengambil suatu pertimbangan etis (Suardika, 2010). Oleh karena itu suatu pertimbangan etis yang baik oleh konsultan pajak diharapkan akan menghasilkan suatu keputusan yang etis didalam melakukan tax planning dan menghindarinya dari dilema etis. Riset terdahulu banyak meneliti tentang bagaimana pengambilan keputusan etis dan dilema etis dalam konsultan pajak. Namun, lebih didominasi dengan hanya melihat hubungan-hubungan dan pengaruh suatu variabel (paradigma positif) terhadap konsultan pajak tetapi tidak secara langsung mencari tahu secara mendalam tentang kesadaran dari diri konsultan pajak itu sendiri, apa yang dirasakan konsultan pajak dalam melakukan tugasnya tersebut. Hal tersebut membuat peneliti merasa tertarik untuk melakukan penelitian pada konsultan pajak dengan menggunakan studi fenomenologi untuk melengkapi hasil dari penelitian-penelitian kuantitatif.

Konsultan pajak satu dan lainnya memiliki pandangan, pendapat, serta kesadaran yang berbeda dalam mengatasi dilema etis pada saat melakukan tax planning untuk kliennya. Perbedaan tersebut dapat muncul karena kondisi yang berbeda dalam diri masingmasing konsultan pajak. Peneliti melalui studi fenomenologi mencoba mencari tahu dan mendalami mengenai bentuk pengalaman, apakah ada situasi dilema etis, pengambilan keputusan etis yang dihadapi oleh konsultan pajak yang dilakukan konsultan pajak dalam memecahkan dilema etis saat melakukan tax planning. Studi fenomenologi dalam penelitian ini bertujuan untuk memahami atau memaknai dan kemudian menginterpretasikan pemaknaan tersebut bukan menjelaskan dan memprediksi suatu hubungan sebagaimana tujuan paradigma positif/ fungsionalis (Noviriani, 2015).

Pendekatan yang digunakan dalam penelitian adalah pendekatan fenomenologi transendental Husserl. Fenomenologi transendental terjadi dalam diri individu 
secara mental (transenden) (Creswell, 2016). Fenomenologi transendental berpedoman pada konsep epoche. Epoche merupakan sikap "pengurungan" pengetahuan dan informasi yang dimiliki peneliti, agar informasi yang diterima murni dari informan. Menggunakan fenomenologi transendental, peneliti ingin mengeksplorasi esensi fenomena berdasarkan kesadaran murni individu. Pendekatan ini meyakinkan peneliti untuk dapat memahami pengalaman konsultan pajak secara mendalam melalui kesadaran murni konsultan pajak sebagai aktor yang terlibat dan mengalami fenomena. Diharapkan, dengan menyelami titik kesadaran aktor tersebut dapat diperoleh gambaran nyata atas realitas pengalaman konsultan pajak dalam menjalani tax planning. Pengambilan informan dilakukan pada konsultan-konsultan pajak yang ada di Kota Denpasar.

\section{Teori}

\subsection{Teori Etika}

Menurut Bertens (2000), teori etika mempunyai suatu tujuan, yaitu membantu individu dalam mengambil suatu keputusan terkait moral serta memberikan pertimbangan atas keputusan yang dibuat. Teori etika dapat dikelompokan menjadi tiga, yaitu: (a) Ultilitarianism yang mengartikan benar atau salah dari suatu tindakan dipengaruhi akibat dari tindakan tersebut; (b) Deontologi dimana tindakan yang dilakukan individu tidak dilakukan hanya berdasarkan tujuan melainkan suatu kewajiban; dan yang terakhir adalah (c) Teori Keutamaan dimana suatu perintah atau jabatan yang diperoleh individu dapat memungkinkan membuat individu bertindak secara moral.

Teori etika sangat berkaitan dengan penyelesaian dilema etika. Teori etika dapat membantu individu dalam mempertimbangkan keputusan yang akan di lakukan untuk menghindarinya dari rasa dilema. Dilema etika adalah dimana individu berada disituasi yang sulit antara memilih dua tindakan yang akan dilakukan saling tidak menguntungkan atau sebanding. Dilema etika sering ditemukan pada perkerjaan profesi tak terkecuali konsultan pajak. Konsultan pajak ditempatkan pada posisi sulit dimana ia harus memilih suatu tindakan serta akibat yang akan ditimbulkan apakah sesuai dengan moral etis atau tidak. Dilema etika dapat di atasi dengan memilih suatu pertimbangan yang baik.

\subsection{Teori Fenomenologi Edmund Husserl}

Fenomenologi mempunyai dua jenis pendekatan, fenomenologi hermeneutika dan fenomenologi transendental (Creswell, 2007). Fenomenologi hermeneutika merupakan penelitian yang berfokus pada pengalaman hidup dan penafsiran dalam kehidupan.
Fenomenologi transendental merupakan informasi yang murni berasal dari informan, yang bebas dari persepsi. Husserl memfokuskan fenomenologi transendental sebagai studi kesadaran. Kesadaran tersebut berpusat pada "aku" sebagai individu, namun berbeda antara satu dengan yang lainnya. Hal ini disebabkan karena pengalaman seseorang satu dengan yang lainnya berbeda. Pengalaman yang berbeda membentuk harapan, persepsi, imajinasi, dan ingatan yang berbeda (Auliyana, 2017).

Fenomenologi dalam konsep kesadaran menurut Husserl bersifat terbuka. Fenomena pengalaman merupakan apa yang dihasilkan oleh aktivitas dan kesadaran manusia. Husserl banyak membahas tentang konsep kesadaran dalam pengalaman, sehingga sampai saat ini fenomenologi diartikan sebagai studi tentang kesadaran dan pengalaman yang ada di dalamnya. Fenomenologi mempelajari bentuk pengalaman dari seseorang yang mengalaminya secara langsung, seakanakan dialami oleh orang yang meneliti tentang pengalaman tersebut. Selain mengklasifikasikan tindakan sadar, fenomenologi juga memprediksi tindakan dimasa yang akan datang sebagaimana memaknai objek dalam pengalaman (Kuswarno, 2009).

Dalam metodologi, fenomenologi bertugas untuk menjelaskan things in themselves, mengetahui sesuatu yang ada sebelum kesadaran, serta memahami makna dan esensisnya, dalam intuisi dan refleksi diri. Husserl mempunyai sebuah konsep dalam metodologi fenomenologi transendental, yaitu epoche (bracketing) merupakan pemisahan hal-hal yang dapat menganggu kemurnian dari sebuah informasi. Peneliti harus masuk kedalam dunia internal yang murni, sehingga dapat memudahkan peneliti dalam memahami informan. Peneliti harus memisahkan ego, prasangka, persepsi, pengetahuan terdahulu yang dimiliki, sehingga fenomena murni dari pengalaman informan, dan terbebas dari campur tangan peneliti. Fenomenologi transendental memiliki unit-unit analisis yang digunakan, yaitu kesengajaan (intentionality), noema dan noesis, intuisi, serta intersubjektivitas.

Kesengajaan (intentionality) merupakan pikiran yang berorientasi terhadap suatu objek. Kesengajaan dipengaruhi terhadap minat, penilaian awal, dan harapan. Noema merupakan sesuatu yang bias didengar, dilihat, dirasakan, dipikirkan, meskipun sesuatu yang masih berupa pemikirian (ide). Noesis merupakan tindakan, seperti merasa, mendengar, memikirkan, dan memberikan penilaian terhadap ide. Hal yang menghubungkan noema dan noesis adalah intuisi. Intersubjektivitas merupakan konsep sosial dan konsep tindakan. Konsep sosial merupakan hubungan antara dua individu atau lebih, sedangkan konsep tindakan merupakan perilaku yang membentuk suatu makna subjektif. Maka, intersubjektif merupakan realitas sosial 
yang dimaknai bersama dengan individu lainnya (Kuswarno, 2009).

\subsection{Fenomenologi Transendental sebagai Metode Memahami Adanya Dilema}

Pemilihan paradigma yang tepat dalam suatu penelitian akan memberikan kemudahan dalam menjawab pertanyaan penelitian dalam suatu penelitian. Dalam penelitian ini, peneliti menggunakan paradigma interpretif. Paradigma interpretif dapat menggali pengalaman atas fenomena dilema etis menurut masingmasing informan yang terlibat langsung dalam situasi tersebut. Dilema etis merupakan suatu fenomena yang dialami oleh konsultan pajak. Konsultan pajak melalui symbol dan bahasa dapat mengungkapkan fenomena yang mereka alami serta cara untuk mengatasinya, selanjutnya peneliti akan memahami dan menginterprestasikannya. Oleh sebab itu paradigma interpretif dianggap cocok untuk menjawab pertanyaan penelitian. Pendekatan yang digunakan pada penelitian ini adalah pendekatan fenomenologi transcendental.

Menggunakan fenomenologi transcendental, peneliti ingin mengetahui lebih dalam mengenai makna dari fenomena berdasarkan kesadaran informan. Fenomenologi transendental meyakinkan peneliti untuk dapat memahami dilema yang dirasakan konsultan pajak melalui kesadaran murni konsultan pajak sebagai aktor yang mengalami dan terlibat dalam fenomena. Peneliti berharap, dengan mendalami titik kesadaran konsultan pajak, peneliti mendapat gambaran nyata atas realitas dilema etis. Penelitian fenomenologi transendental mengacu pada tahap-tahap analisis data berdasarkan beberapa peneliti, seperti Van Kaam Tahun 1966 dan Colaizzi Tahun 1978 serta dimodifikasi oleh Moustakas (1994). Sama seperti yang diungkapkan Kuswarno (2009), metode fenomenologi transendental memiliki empat tahap, yaitu: epoche, reduksi fenomenologi, variasi imajinatif, dan sintesis antara makna dan esensi.

\section{Metode Penelitian}

\subsection{Informan Penelitian dan Tahap Pengumpulan Data}

Dalam penelitian kualitatif, teknik pemilihan informan yang paling umum digunakan adalah snowball sampling. Teknik snowball sampling, subjek dipilih berdasarkan rekomendasi orang ke orang yang sesuai dengan penelitian dan terkuat untuk diwawancarai (Patton dalam Putu, 2009). Teknik tersebut melibatkan beberapa informan yang berhubungan dengan peneliti. Informan ini akan menghubungkan peneliti dengan orang-orang yang cocok dijadikan narasumber penelitian.

Peneliti meminta rekomendasi calon informan dari salah satu subjek yang dikenal. Setelah itu, peneliti meminta rekomendasi subjek berikutnya yang sesuai dengan karakteristik penelitian ini, dan begitu pula seterusnya (Fitriani, 2014). Oleh sebab itu informan dalam penelitian ini merupakan informan yang menurut pertimbangan peneliti merupakan orang yang tepat dan tentunya sangat berkaitan dengan penelitian ini, yaitu lima konsultan pajak Kota Denpasar yang terdaftar dalam IKPI.

Tabel 1 Daftar Informan

\begin{tabular}{|c|l|ll|}
\hline No & \multicolumn{1}{|c|}{$\begin{array}{c}\text { Nama } \\
\text { Konsultan Pajak }\end{array}$} & \multicolumn{1}{|c|}{ Alamat } \\
\hline 1. & $\begin{array}{l}\text { I Kadek Agus } \\
\text { Ardika }\end{array}$ & Jl. Kenyeri No. 65 Denpasar \\
\hline 2. & Riza Edwindra & $\begin{array}{l}\text { Jl. Kecubung No.7 } \\
\text { Denpasar }\end{array}$ \\
\hline 3. & $\begin{array}{l}\text { Ni Komang } \\
\text { Rahayu Antari }\end{array}$ & Jl. Gemitir No.56 Denpasar \\
\hline 4. & $\begin{array}{l}\text { Maurin Dewiati } \\
\text { Harianto }\end{array}$ & Jl. Suli No. 40 Denpasar \\
\hline 5. & $\begin{array}{l}\text { Ni Wayan } \\
\text { Sumarni }\end{array}$ & $\begin{array}{l}\text { Jl. Tukad Buaji No. 2 } \\
\text { Denpasar }\end{array}$ \\
\hline
\end{tabular}

Sumber: Hasil analisis, 2018

Kelima informan tersebut dirasa tepat oleh peneliti untuk menjawab pertanyaan dalam penelitian ini. Sebab masing-masing informan mempunyai tugas yang sama, dan memiliki pengalaman diatas tiga tahun. Informan dalam tugas yang sama dipastikan mempunyai pengalaman, dilema yang dirasakan, serta bagaimana pertimbangan yang dilakukan untuk mengatasi dilema tersebut. Sehingga pertanyaan dalam penelitian ini akan terjawab. Sebelum melakukan pengumpulan data dilapangan, peneliti terlebih dahulu melakukan tahapantahapan pengumpulan data pada penelitian fenomenologi yang diilustrasikan oleh Creswell (2007).

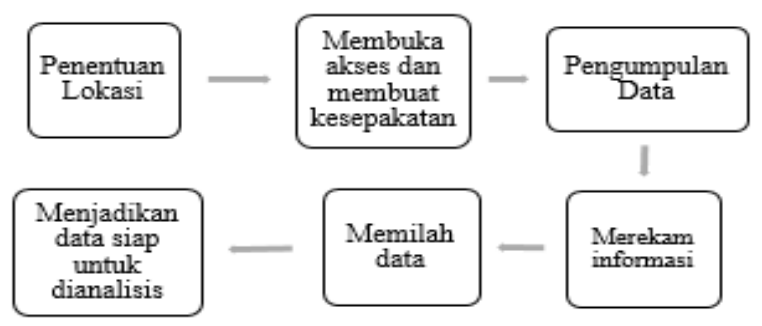

Gambar 1 Tahap Pengumpulan Data Sumber: Creswell (2007)

Menurut Moleong (2017) adanya proses dalam suatu penelitian dapat memperjelas pengamatan pada objek penelitian. Proses dalam penelitian ini menggunakan fenomenologi sebagai alat analisis untuk memaknai bagaimana konsultan pajak dalam menghadapi dilema etis. Analisis data yang dilakukan oleh penulis mengacu pada teknik analisis data yang sesuai dengan pendekatan studi fenomenologi trandental Husserl, yaitu Moustakas (1994). Moustakas (1994) memodifikasi penelitian Van 
Kaam Tahun 1966 dan Colaizzi Tahun 1978 mengenai langkah-langkah dalam penelitian fenomenologi transendental dengan menggunakan beberapa tahapan analisis data.

Tahap analisis data tersebut terdiri dari proses reduksi fenomenologi yaitu: horizonalization, dan textural description), variasi imajinatif (structual description) serta menggabungkan antara makna dan esensi (Noviriani, 2015). Tahap pertama, peneliti mengorganisasikan keseluruhan data tentang fenomena pengalaman yang telah dikumpulkan melalui wawancara, serta memeriksa kembali kelengkapan, kejelasan makna, kesesuaian dan relevansi satu data dengan data yang lainnya. Tahap kedua, peneliti membaca data secara menyeluruh dan mencatat mengenai data yang penting serta melakukan pengkodean data. Tahap ketiga, peneliti menemukan dan mengkelompokkan makna dari pernyataan yang dirasakan informan terhadap fenomena, dan menghilangkan pernyataan yang tidak relevan maupun yang tumpang tindih dengan topik pertanyaan sehingga arti tekstural dan unsur penyusun dari fenomena tidak mengalami penyimpangan (horizons).

Tahap keempat, peneliti mengumpulkan pernyataan yang diperoleh kedalam unit makna (cluster of meaning) kemudian peneliti menulis gambaran tentang bagaimana pengalaman tersebut terjadi. Tahap kelima, peneliti mengembangkan fenomena apa yang terjadi pada informan (textural description) dan menjelaskan bagaimana fenomena itu terjadi (structural description). Tahap keenam, peneliti memberikan penjelasan secara naratif mengenai esensi dari fenomena yang diteliti serta mendapatkan makna pengalaman informan mengenai makna tersebut. Tahap terakhir, peneliti menemukan fenomena dan ditulis berdasarkan dari gabungan deskripsi gambaran yang diperoleh (composite description).

\section{Hasil Penelitian dan Pembahasan}

\subsection{Bentuk Dilema: Ketidakjelasan Peraturan yang Menempatkan Konsultan Pajak didalam Dilema}

Konsultan pajak dituntut untuk berkerja sesuai dengan peraturan undang-undang dan kode etik. Namun, disisi lain dalam penerapan suatu aturan dan kenyataan dilapangan sangat berbeda dengan apa yang ada di dalam peraturan. Dalam membuat suatu perencanaan pajak, diperlukan pemahaman yang tinggi mengenai aturan dalam undang-undang pajak untuk menghindari resiko atau memperkecil resiko saat jika terjadi pemeriksaan. Undang-undang perpajakan mempunyai area "abu-abu" yang kerap dimanfaatkan dalam membuat perencanaan pajak. Grey area atau "area abu-abu" merupakan peraturan yang tidak jelas dan tidak tegas, namun tidak ada penjelasan apakah boleh dilakukan atau tidak.
Konsekuensinya jika di terap kan juga tidak jelas sehingga memunculkan berbagai persepsi. Sebagaimana yang diungkapkan oleh konsultan pajak Riza Edwindra sebagai berikut:

"Ya kita mainnya ya memanfaatkan itu grey area itu....Grey area itu sebenernya aturan yang gak teges, dia bilang boleh tp gak ada petunjuknya, dia bilang gak boleh tp gak ada hukumannya" (Jum'at, 22 Juni 2018: 14.00 WITA).

Dalam pernyataan "mainnya memanfaatkan grey area" dapat ditarik kesimpulan bahwa bukan hal yang tabu lagi bagi konsultan pajak dalam melakukan penghematan pajak klien dengan memanfaatkan celah dalam suatu peraturan. Hal ini dapat memberikan pemahaman bahwa peraturan pajak di Indonesia masih belum ketat tercermin dari pernyataan "aturan yang gak teges". Dapat ditarik kesimpulan bahwa undang-undang pajak memang masih memiliki ketidaktegasan aturan yang ada didalamnya sehingga dalam peraturan yang ditetapkan pun dapat digunakan klien untuk melakukan penghematan pajak.

Undang-undang pajak memiliki banyak peraturan pasal-pasal yang dapat dijadikan suatu celah untuk membuat perencanaan pajak, celah dalam pasal tersebut terdapat dalam kalimat dari pasal itu sendiri. Menggukanan celah tersebut dalam membuat perencanaan pajak harus menentukan arti celah dari pasal terlebih dahulu, sehingga jika diterapkan konsultan pajak dapat meminimalisir resiko yang akan terjadi. Namun, konsultan pajak kerap masih merasa kesulitan untuk menentukan arti dari celah tersebut seperti yang diungkapkan oleh konsultan pajak Riza Edwindra:

"Aturannya itu ada bilang lainnya, nah menentukan lainnya ini yang susah.. grey area kan gak jelas ya.. lainnya gmn" (Jum'at, 22 Juni 2018: 14.00 WITA). Dalam undang-undang pajak ada pasal-pasal yang aturannya tidak jelas karena tidak lengkap seperti contoh yang diungkapkan konsultan pajak Riza. Kalimat dalam pasal menyebutkan kata "lainnya". Konsultan pajak dalam hal ini harus mencari tahu secara mendalam arti dari kata "lainnya", apa saja aturan yang termasuk atau tidak termasuk dari kata tersebut. Aturan yang banyak membuat konsultan pajak kerap merasakan kesusahan dalam mengira-ngira dan menentukan kata "lainnya" berupa apa dan resikonya bagaimana jika diterapkan. Oleh sebab itu grey area terkadang memberikan rasa dilema kepada konsultan pajak disaat akan menggunakan area tersebut dalam membuat perencanaan pajak. Konsultan pajak mempunyai rasa keyakinan yang kurang ketika akan menggunakan area "abu-abu" yang ada di dalam peraturan.

Hal ini disebabkan karena peraturan yang akan digunakan tidak jelas, sehingga menimbukan persepsi yang berbeda. Persepsi yang berbeda akan memicu adanya perbedaan pendapat antara klien dan pemeriksa 
pajak. Sehingga jika resikonya tidak diantisipasi terlebih dahulu hal ini dapat menjadi suatu sengketa pajak. Oleh sebab itu, konsultan pajak merasa kurang yakin dalam memberikan masukan kepada kliennya, jika peraturan masih dalam area "abu-abu". Seperti yang di ungkapkan oleh konsultan pajak Kadek Agus sebagai berikut:

"Yang menjadi dilema itu karena grey....dilema itu pas memberi masukan kepada klien, keyakinan tu gak $100 \%$ gek, kenapa gak $100 \%$ karena aturannya masih grey, penafsirannya berbeda" (Senin, 18 Juni 2018: 13.28 WITA).

Lebih lanjut, Kadek Agus menambahkan:

"Dilema gek, pada saat memberikan advise, karena mengapa...disisi lain kantor pajak ingin menetapkan sesuai dengan pasal, namun substansinya dilapangan gak bisa gek, jadi sudah pasti dilema..khawatir planning kita benar atau tidak..."(Senin, 18 Juni 2018: 13.28 WITA).

Mimik wajah saat Kadek Agus menyatakan "dilema saat memberikan advise" serta "khawatir planning kita benar atau tidak" seperti merasa bersalah, dan sedikit putus asa. Hal ini seperti mengungkapkan dilema yang cukup mendalam yang dirasakan saat memilih celah yang akan digunakan dalam perencanaan pajak. Dilema menyebabkan rasa kekhawatiran dimana jika saat memberikan masukan kepada klien mengenai celah dalam peraturan yang dapat digunakan untuk penghematan pajaknya, namun ternyata celah tersebut dapat menimbulkan resiko yang besar saat terjadi pemeriksaan hanya karena perbedaan persepsi dengan petugas pajak. Tidak hanya menimbulkan resiko untuk wajib pajak yang dimana sebagai klien dari konsultan pajak, namun resiko tersebut juga dapat mengenai konsultan pajak seperti yang diungkapkan oleh konsultan pajak Riza Edwindra sebagai berikut:

"grey area, kalo ternyata terbukti gak boleh, gak jadi grey ya jadinya.ha.ha ya saya bisa kena" " (Jum'at, 22 Juni 2018: 14.00 WITA).

Pernyataan "terbukti gak boleh" yang diungkapkan Riza Edwindra, dapat ditarik kesimpulan bahwa grey area tidak selalu boleh untuk dilakukan. Jika terbukti bahwa penafsiran dari grey area yang ada didalam sebuah aturan tersebut tebukti tidak boleh dilakukan dalam hal terbukti melanggar, ataupun salah penafsiran dari grey area, sehingga menjadi suatu masalah dalam pemeriksaan pajak, maka tidak hanya wajib pajaknya saja yang kena tetapi juga konsultan pajaknya, seperti pada kalimat "ya saya bisa kena" yang diungkapkan oleh Riza Edwindra. Oleh sebab itu pertimbangan konsultan pajak untuk memanfaatlan celah dari suatu peraturan dalam membuat perencanaan pajak klien, sangatlah harus berhati-hati. Sebab jika salah dalam memanfaatkan celah, dapat memberikan resiko kepada klien jika nantinya dilakukannya pemeriksaan.
Melalui beberapa pernyataan oleh konsultan pajak diatas, diperoleh pemahaman bahwa dilema yang dialami oleh konsultan pajak dikarenakan peraturan yang masih "abu-abu". Petugas pajak ingin menetapkan aturan sesuai dengan pasal, namun substansinya dilapangan tidak bisa sesuai dengan pasal. Hal ini di sebabkan adanya "area abu-abu" tersebut. Konsultan pajak dalam membuat perencanaan pajak menggunakan "area abu-abu" dari peraturan. Namun, "area abu-abu" dapat membuat persepsi yang berbeda antara petugas pajak dan wajib pajak. Hal ini menyebabkan konsultan pajak merasa dilema dan merasa tidak yakin serta khawatir akan "area abu-abu" yang digunakan dalam membuat perencanaan pajak, apakah perencanaan pajak yang disarankannya ke klien benar atau salah. Konsultan pajak ingin agar kliennya dan dirinya sendiri tidak terkena resiko saat adanya pemeriksaan pajak. Namun, disisi lain adanya penafsiran yang berbeda antara petugas pajak dan dirinya, peraturan dan substansinya membuat konsultan pajak tidak memiliki keyakinan secara penuh dalam membuat perencanaan pajak.

\subsection{Bentuk Dilema: Kepedulian akan Kondisi Klien Menempatkan Konsultan Pajak di dalam Dilema}

Sebagai seorang manusia tentunya mempunyai rasa kepedulian terhadap sesama manusia. Hal ini disebabkan karena diluar logika pikiran dan ego, manusia masih memiliki hati nurani yang dapat memberikan suatu perasaan iba dan kasihan terhadap sesama manusia. Tak terkecuali konsultan pajak. Diluar tugasnya sebagai konsultan pajak, ia tetaplah seorang manusia biasa yang juga memiliki hati nurani. Hal ini pun berpengaruh terhadap tugasnya sebagai konsultan pajak. Sebagai seorang konsultan harus berpegang teguh pada prinsip dari kode etik yaitu membantu membimbing klien (wajib pajak) untuk patuh dan taat kepada peraturan yang berlaku. Dalam hal perencanaan pajak, konsultan pajak seharusnya membimbing kliennya untuk patuh dalam melaporkan omset yang sesungguhnya, sehingga pajak yang harus dibayar klien akan sesuai dengan omsetnya. Namun, pada kenyataan dilapangan klien (wajib pajak) data omset yang diberikan kerap tidak riil. Seperti yang dinyatakan oleh konsultan pajak Wayan Sumarini berikut:

"Kadang-kadang kan klien itu juga kayak sembunyi ya dari kita, kita kan juga gak terlalu pingin tau ya urusan omsetnya dia, ada juga yang memang terbuka riil datanya" (Selasa, 14 Juni 2018: 13.47 WITA).

Pernyataan "kayak sembunyi dari kita" dari konsultan pajak Wayan Sumarini membuktikan bahwa wajib pajak kerap menyembunyikan omset perusahaan yang sesungguhnya, hal ini dikarenakan untuk menekan pembayaran pajak yang besar alih-alih demi kelangsungan perusahaannya. Pernyataan "terbuka riil 
datanya" memunculkan pemikiran bahwa sebenarnya ia juga mengetahui jika kliennya memberikan data omset yang tidak sesungguhnya. Ini disebabkan karena konsultan pajak akan tetap menghitung data-data yang diberikan, guna untuk mencocokan apakah data yang diberikan sudah benar atau tidak. Konsultan pajak jika mendapati data yang tidak riil seharusnya menolak data yang tidak riil dan melaporkannya langsung data yang riil. Namun kembali lagi dari sisi nurani, konsultan pajak kerap merasakan rasa kasihan terhadap kliennya jika melihat kondisi perusahaan klien, seperti yang diungkapkan konsultan Wayan Sumarini berikut ini:

"Niatnya klien jg kadang-kadang pingin jujur, tapi apa daya kan ada tengang waktu ya, kan kurang bayarnya besar, sehingga dia gak punya uang" (Selasa, 14 Juni 2018: 13.47 WITA).

Lebih lanjut, Wayan Sumarini menambahkan:

"Kalo saya ya yang penting kliennya itu seumpama kalo gajah jangan ngaku semut" (Selasa, 14 Juni 2018: 13.47 WITA).

Pernyataan "pingin jujur" memunculkan pemikiran bahwa terkadang wajib pajak ingin jujur melaporkan omset yang sesungguhnya, namun karena terbatas biaya untuk operasional perusahaan menimbulkan rasa ingin menyembunyikan omset agar bisa melakukan penghematan pajak sehemat mungkin sehingga pajak yang akan dibayarkan kecil, sesuai dengan pertanyaan "dia gak punya uang". Namun, pernyataan "gajah jangan ngaku semut" juga menimbulkan pemikiran bahwa tidak semua klien itu jujur dalam mengungkap seberapa besar perusahaannya. Disini lah tugas konsultan pajak untuk mencari tahu secara jelas tentang klien yang sedang ditanganinya, sehingga bisa meminimalisir resiko jika terjadinya pemeriksaan pajak. Konsultan pajak pada prinsipnya harus membina klien untuk patuh membayar pajak. Tidak seharusnya konsultan pajak mendukung kliennya untuk melaporkan omset yang tidak riil. Hal ini pun memicu dilema seperti yang di ungkapkan oleh konsultan pajak Kadek Agus:

"Klien yang tetap ngotot gak mau riil juga ada gek, saya pernah ada nanganin klien besar besar sekali itu gek, tapi omsetnya cuma 10 miliyar dulu, wah ngikutin terus maunya, planning terus, dilema gek" (Senin, 18 Juni 2018: 13.28 WITA).

Lebih lanjut, Kadek Agus menambahkan:

"Dilemanya juga kita tau riilnya, berapa omset riilnya, dilema banget kita, etis gak kita menjalankan? Kita gak etis, tapi tujuan kita bukan membunuh perusahaan" (Senin, 18 Juni 2018: 13.28 WITA).

Pernyataan Kadek Agus mengindikasikan bahwa ia pernah mendapat klien yang "ngotot gak mau riil" namun ia tetap mengikuti kemauan klien seperti dalam pernyataannya "ngikutin terus maunya, planning terus, dilema gek". Hal ini memunculkan pemikiran bahwa sebenarnya ia sebagai konsultan pajak telah membina klien untuk patuh terhadap aturan, namun disisi lain klien tetap tidak bisa untuk melaporkan data yang riil. Kadek Agus menambahkan "bukan untuk membunuh perusahaan" mengindikasikan bahwa demi untuk tidak "membunuh" klien, ia memutuskan untuk membantu klien, walaupun ia tahu bahwa hal yang dilakukannya melanggar dari prinsip konsultan pajak. Hal ini menyebabkan dilema yang cukup mendalam yang ia rasakan terlihat dari mimik wajahnya karena ia "tau riilnya" namun ia tetap mendukung wajib pajak untuk melaporkan yang tidak riil dengan alasan tidak ingin "membunuh" perusahaan.

Melalui beberapa pernyataan oleh konsultan pajak diatas, dapat ditarik kesimpulan bahwa dilema yang konsultan pajak rasakan adalah saat seharusnya konsultan pajak melaporkan omset riil dari kliennya namun disisi lain konsultan pajak peduli akan kelangsungan perusahaan klien. Konsultan pajak dalam membuat suatu perencanaan pajak harus dengan data yang riil untuk menghindari resiko jika terjadi pemeriksaan. Selain itu data yang tidak riil bisa mengarah ke dalam area tax evasion. Konsultan pajak seharusnya mengindari hal ini, sehingga hasil pajak yang harus dibayar dapat sesuai dengan omset dari klien dan tidak menimbulkan masalah dikemudian hari. Disisilain, konsultan pajak masih memiliki rasa simpati dengan merasa kasihan melihat kondisi perusahaan klien. Hal ini menyebabkan konsultan pajak terjebak dalam suatu kebingungan yang mendalam.

\subsection{Pengalaman Konsultan Pajak dalam Mengatasi Dilema Memahami Peraturan untuk Mengatasi Dilema}

Setiap profesi memiliki peraturan dan kode etik yang menjadi dasar dalam menjalankan tugas-tugasnya. Begitu pula dengan konsultan pajak, dimana konsultan pajak memiliki undang-undang pajak dan kode etik yang menjadi pondasi untuk menjalankan tugas-tugasnya sebagai seorang konsultan. Pada dasarnya, peraturan dan kode etik berfungsi untuk menjaga konsultan pajak agar sesuai dan didalam jalan yang benar tidak menyimpang dari peraturan. Namun, suatu peraturan kerap memberi suatu celah konsultan pajak untuk memanfaatkannya dalam membuat tax planning. Celah tersebut sering disebut dengan "area abu-abu". Tax planning dengan menggunakan area "abu-abu" tersebut masih dapat dikatan dalam batas legal. Namun, area "abu-abu" pun tak jarang membuat penafsiran berbeda antara petugas pajak dan konsultan pajak. Hal ini membuat dilema bagi konsultan pajak dalam menyampaikan pendapat kepada klien mengenai celah-celah mana saja yang dapat digunakan untuk melakukan penghematan. 
Konsultan pajak dalam hal ini harus benar-benar mempunyai kesadaran untuk memahami secara baik aturan-aturan dalam undang-undang dan kode etik. Memahami peraturan secara tidak langsung menyebabkan konsultan pajak lebih berhati-hati atas pengambilan keputusan yang akan di ambil. Seperti yang di ungkapkan oleh konsultan pajak Kadek Agus berikut ini:

"Ibarat dulu kita melakukan sesuatu gak tau aturan, hantam terus aja..setelah tau aturan undangundangnya seperti apa, akhirnya kita semakin bukan berarti tambah berani ya, tapi tambah berhati-hati.." (Senin, 18 Juni 2018: 13.28 WITA).

Kadek Agus dalam pernyataannya menceritakan dahulu sebelum ia mengerti tentang aturan, ia sama sekali tidak merasakan ke khawatiran ataupun dilema akan resiko yang disebabkan jika ia salah dalam memberikan tax planning, namun saat ia mengerti tentang aturan ia merasakan bahwa mengerti suatu undang-undang membuat ia bertambah hati-hati dalam mengambil setiap langkah dalam melakukan tugasnya salah satunya dalam memberikan tax planning. Hal ini memunculkan pemikiran bahwa, memang seharusnya suatu peraturan menjadi pedoman bagi konsultan pajak agar lebih berhati-hati pada setiap tindakan yang ia lakukan dan tidak menyimpang dari peraturan.

Memahami sebuah peraturan juga memiliki keterkaitan dalam mengatasi sebuah dilema. Dilema dapat terjadi akibat perbedaan penafsiran antara aturan yang tercantum di area "abu-abu" dengan situasi dilapangan atau dengan kata lain, perbedaan penafsiran konsultan pajak dan petugas pajak dalam memahami sebuah peraturan. Dilema yang terjadi berkaitan saat konsultan pajak akan memilih suatu celah dalam peraturan untuk melakukan tax planning namun ia merasa khawatir akan benar atau tidaknya keputusan yang diambil. Kekhawatiran disebabkan area yang masih "abu-abu" sehingga jika salah penafsiran akan membawanya dan klien ke dalam resiko yang berat. Namun, dilema ini dapat diminimalisir dengan memahami aturan secara mendalam, sehingga rasa ke khawatiran dalam melakukan tax planning dengan memanfaatkan celah peraturan dapat berkurang. Seperti yang di ungkapkan oleh konsultan pajak Kadek Agus berikut:

"saya meyakini diri dengan membuat skema aturan dulu....kemudian substansinya apa, jadi kira-kira orang pajak begini..ketemunya dimana..kalau kayak di hukum itu kita harus buat seperti pra kasus, jika diketemukan begini pemecahannya gimana" (Senin, 18 Juni 2018: 13.28 WITA).

Kadek Agus menggambarkan hal yang ia lakukan untuk "meyakinkan diri"-nya, yaitu dengan cara membuat skema aturan terlebih dahulu. Hal ini berarti ia harus memahami secara benar dari aturan yang akan ia gunakan dalam membuat suatu keputusan tax planning. Setelah itu ia akan mencocokan kepada substansinya seperti apa, serta memprediksikan penemuan yang ditemukan oleh pemeriksa pajak sehingga resiko dapat di hindari dengan menyiapkan data yang diperlukan atau argument-argumen yang diperlukan. Kadek Agus memberikan contoh sebagai berikut:

"jadi misalnya saya harus melihat substansinya, jadi mencari kepastian itu penekananya disubstansi, jadi perlakuannya apa sih..? ini gimana secara akuntansi kan ada PSAK jadi kita harus bandingkan, kadang undang-undang pajak tidak match dengan PSAK...Jadi kita mencari celah yang meyakinkan di undang-undang gak diatur itu, di PSAK diatur, kalo di PSAK diatur ya keyaknan kita ya pasti $100 \%$ akan menang, seandainya ini menjadi masalah" (Senin, 18 Juni 2018: 13.28 WITA).

Kadek Agus memberikan contoh berkaitan dengan kasus perpajakan dan akuntansi. Tax planning membutuhkan data-data keuangan perusahaan seperti pembukuan perusahaan. Terkadang undang-undang PSAK dan perpajakan terdapat ketidakesamaan. Hal ini menyebabkan untuk meyakinkannya dalam mencari suatu celah membuat tax planning Kadek Agus harus membandingkan undang-undang PSAK dan undangundang pajak. Sehingga ia yakin jika terjadi suatu perdebatan, keyakinan yang ia miliki $100 \%$ dapat memenangkan perdebatan tersebut dikarekanan ia memiliki undang-undang pembanding untuk digunakannya dalam beragumen. Oleh sebab itu pemahaman yang baik dari peraturan sangatlah penting untuk menghindarinya dari resiko dalam membuat tax planning. Kadek Agus menekankan:

"jadi kita mencari celah yang meyakinkan...jika yakin ya lakukan” (Senin, 18 Juni 2018: 13.28 WITA).

Penekanan Kadek Agus dalam "mencari celah yang meyakinkan" menjelaskan bahwa, dalam meyakinkan diri akan suatu celah mempunyai beberapa langkah seperti memahami peraturan, memprediksikan apa yang seandainya terjadi dan menyiapkan data-data serta menguatkan argumen. Sehingga jika semua peraturan dipahami dan segala sesuatu yang diperlukan sudah siap, maka ia pun merasa yakin untuk memberikan advise kepada klien dan melakukan planning. Kadek Agus dalam memberikan advise juga lebih menekankan penyampaian riil ke pada klien terlebih dahulu mengenai resiko yang akan terjadi ketika seandainya kantor pajak memeriksa, seperti yang diungkapkan berikut ini:

"Kuncinya gek menyampaikan riil gek, sama dengan gek misalnya, gek gak boleh begini ya ini ini ini, jadi kita udah kasi tau riilnya gini, terus gek bilang tapi ini bisa gak di kecilkan, oh ini bisa bisa bisa, tapi kalau ini di jalankan harus ada bukti ini, ini, jadi gek 
tau riilnya kayak gini, kalau seandainya kantor pajak meriksa ya gak? Apa yg diperiksa sama kayak yang kita analisis, kan wp paham, oh uda dikasi tau kok, gak masalah bagi saya, jadi kita yakin membuat suatu tax planning, harus bener-bener infomasi dengan riilnya dulu, apasih yang jadi resiko buat diambil, apa yang menjadi perdebatan seandainya itu dilakukan" (Senin, 18 Juni 2018: 13.28 WITA).

Pernyataan Kadek Agus mengindikasikan bahwa kliennya harus mengetahui terlebih dahulu mengenai data yang riil. Jika klien menginginkan tax planning, Kadek Agus akan terlebih dahulu mencocokan dengan aturanaturan serta memberikan prediksi dan menganalisis apa saja bukti-bukti yang mungkin dibutuhkan ketika terjadi pemeriksaan. Sehingga keyakinan Kadek Agus dalam membuat suatu tax planning menjadi sepenuhnya yakin dan meminimalisir dilema yang ia rasakan. Selaras dengan yang diungkapkan konsultan pajak Riza Edwindra berikut ini:

"Beda penafsiran ini paling akan mengakibatkan sengketa pajak, tapi biasanya argument yang harus di kuatkan saat adanya pemeriksaan pajak" (Jum'at, 22 Juni 2018: 14.00 WITA).

Riza Edwindra mengungkapkan bahwa "argumen yang harus dikuatkan" mengindikasikan bahwa dalam mengatasi perbedaan penafsiran antara petugas pajak dan konsultan pajak memerlukan argument yang kuat untuk memenangkan sengketa tersebut. Argumen yang kuat harus didasari dengan pemahaman dari peraturan yang berlaku. Jika konsultan pajak tidak memahami peraturan, maka dapat dipastikan konsultan pajak tidak akan bisa memberikan argument yang kuat.

Melalui pernyataan dari pengalaman yang diungkapkan oleh konsultan pajak diatas, dapat dipahami bahwa suatu dilema dalam penerapan tax planning dapat diminimalisir dengan memahami peraturan. Konsultan pajak dalam menerapkan tax planning harus tetap sesuai dengan peraturan melalui cara memanfaatkan celah yang ada dalam peraturan tersebut. Namun, terkadang penafsiran dari celah tersebut dapat menimbulkan suatu permasalahkan bahkan resiko yang besar hingga mengarah ke penyimpangan dari aturan. Hal ini menyebabkan dilema dalam pemilihan celah yang akan digunakan. Dilema dapat diminimalisir dengan pemilihan celah yang baik. Hal ini dapat dilakukan dengan pemahaman secara penuh terhadap peraturan yang berlaku, membandingkan peraturan-peraturan lain yang dibutuhkan, menganalisis dan memprediksikan resiko, serta memberikan informasi kepada klien.

\subsection{Membangun Kesadaran Wajib Pajak untuk Mengatasi Dilema}

Meningkatkan pajak dalam suatu negara sangatlah bergantung pada kesadaran wajib pajaknya
(Giarti, 2012). Meningkatkan kesadaran wajib pajak dapat dilakukan dengan memberikan sosialisasi dan membina wajib pajak. Pada dasarnya wajib pajak mempunyai sifat yang berbeda dalam memenuhi kewajiban perpajakannya. Tak jarang juga wajib pajak menggunakan jasa konsultan pajak bukan untuk ingin diberikan pemahaman menenai perpajakan tetapi ingin dibantu dalam meminimalisasikan pajaknya.

Dilapangan, wajib pajak kerap meminta wajib pajak untuk membantunya meminimalisasikan pajaknya bahkan menyembunyikan omset riilnya agar pajak yang harus dibayar lebih sedikit. Konsultan pajak kerap membantu dengan memberikan tax planning yang masih dalam lingkup aturan (legal) dengan pemanfaatan celahcelah dalam suatu aturan. Namun terkadang wajib pajak merasa kurang, dan meminta penghematan yang bahkan mengarah ke arah penyimpangan. Belum lagi, wajib pajak yang menyembunyikan omset riilnya karena alasan tertentu guna meminta simpati terhadap konsultan pajak. Disinilah suatu pertimbangan etis yang baik oleh konsultan pajak diperlukan agar menghindarinya dari suatu dilema. Pertimbangan etis yang dilakukan konsultan pajak lebih banyak kearah menentukan cara atau "taktik" yang membuat wajib pajak awalnya tidak patuh menjadi patuh, seperti pengalaman yang diungkapkan oleh Kadek Agus berikut ini:

"tipikal klien nakal sudah pasti ada, tapi kita hanya membina, ayo, tax planning kita kasi tau yang bener, ya kita tau lah udah banyak yg disembunyikan kita terima-terima aja gitu lo, bukan berarti kita nolak, tapi bukan berarti kita keputusan nerima dengan alasan uang gek...saya mencari klien yang mau belajar, mau memahami" (Senin, 18 Juni 2018: 13.28 WITA).

Sebagai konsultan pajak, Kadek Agus menjelaskan bahwa tipikal wajib pajak beragam. Ada yang patuh akan peraturan, dan ada juga yang "nakal". Mengatasi wajib pajak (klien) yang "nakal", ia pada awalnya tetap menerima permintaan klien untuk meminimalisasi pajaknya maupun menerima pemberian data yang tidak riil oleh klien. Alasan ia menerima bukan semata-mata dengan "alasan uang". Namun, ia ingin membina klien tersebut agar mau belajar dan memahami aturan perpajakan. Memang, menerima permintaan dan data klien yang tidak riil menempatkan konsultan pajak pada dilema. Mengapa? karena hal tersebut merupakan sesuatu yang menyimpang dari peraturan. Tetapi disisi lain konsultan pajak mempunyai rasa simpati dan rasa ingin tahu terhadap kondisi klien, kondisi perusahaan klien, apa alasannya tidak patuh dan menyembunyikan omsetnya. Seperti yang dirasakan konsultan pajak Kadek Agus berikut ini:

"klien yang tetap ngotot gak mau riil juga ada gek, saya pernah ada nanganin klien besar.. besar sekali 
itu gek, omsetnya cmn 10 miliyar dulu, wah ngikutin terus, planning terus, bina terus... dilema gek..dilemanya juga kita tau riilnya, berapa omset riilnya, dilema banget kita, etis gak kita menjalankan? Kita gak etis, tapi tujuan kita bukan membunuh perusahaan, tapi bagaimana perusahaan memahami kesalahan dia, sekarang omsetnya udah 130 miliyar, karena kita yakini gek, periode waktu ini akan membentuk mereka" (Senin, 18 Juni 2018: 13.28 WITA).

Kadek Agus mengungkapkan adanya rasa dilema mengikuti keinginan klien. Namun ia mempunyai suatu tujuan yaitu klien "memahami kesalahannya". Jika ia menolak atau langsung melaporkan kliennya sebagai tindak penggelapan pajak, sama dengan ia "membunuh", sehingga klien selamanya tidak akan memahami tentang pajak. Rasa kesadaran klien akan pajak tidak akan pernah ada. Kadek Agus dalam hal ini ingin kliennya memahami kesalahannya. Bagaimana klien memahami kesalahannya? Sejalan dengan ia menuruti keinginan kliennya, ia terus memberikan pehamanan kepada kliennya, memberi tahu informasi kepada kliennya, memberi tahu hal-hal yang salah. Kadek Agus meyakini bahwa waktu yang akan mengubah kliennya. Sedikit demi sedikit, waktu demi waktu, ia memberikan pengarahan secara halus kepada kliennya sehingga kliennya yang dahulu menyembunyikan omset besarbesaran perlahan-lahan mau membuka sedikit demi sedikit dari omset riilnya.

Oleh sebab itu, memahami peraturan perpajakan akan membuat wajib pajak mempunyai rasa peduli terhadap perpajakan. Ketika wajib pajak mempunyai rasa peduli, wajib pajak akan lebih patuh dalam melaporkan pajaknya. Seperti pernyataan pengalaman lebih lanjut oleh konsultan pajak Kadek Agus berikut:

"jadi kita berikan pemahaman jadi wpnya paham, dia kesadaran sendiri setelah ktia berikan informasi aturan, masukan-masukan, dia sendiri yang mau.." (Senin, 18 Juni 2018: 13.28 WITA).

Sesuai dengan tugasnya sebagai konsultan pajak, Kadek Agus mempunyai cara untuk mengatasi dilemanya dengan membangun kesadaran dari kliennya. Ia membangun kesadaran wajib pajak dengan cara memberikan pemahaman tentang informasi perpajakan, aturan perpajakan, dan masukan-masukan, sehingga rasa sadar dari wajib pajak pun muncul dengan sendirinya dan wajib pajak sedikit demi sedikit berubah kearah yang lebih patuh dalam melaksanakan kewajiban perpajakannya. Selaras dengan konsultan pajak Riza Edwindra. Ia mengatasi rasa dilemanya dengan cara awal yang sedikit berbeda namun tetap pada intinya yaitu memberikan pemahaman kepada kliennya, seperti yang diungkapkannya berikut ini:

"saya setengah tutup mata aja sih gek..saya kasik aja kontrak, jadi isinya semua data yang km kasi kesaya itu saya anggap benar, klo semisal salah ya sono...kmrn saya gitukan klien saya yg bandel malah sampe ngambul dia gek..tp saya sih tetep kasi tau ya akhirnya mungkin dia takut ya, saya udah tau juga dia ngumpet, dan dia udah tanda tangan kontrak..ya..jadi dia nurut aja gitu ha..ha" (Jum'at, 22 Juni 2018: 14.00 WITA).

Konsultan pajak Riza Edwindra mengungkapkan bahwa ia "setengah tutup mata" yang dalam artian, ia tidak mengetahui data yang diberikan itu riil atau tidak. Namun, untuk menekan kliennya ia menggunakan suatu "kontrak kerja" kepada kliennya. Jadi jika klien tersebut terbukti salah, resiko ditanggung oleh klien itu sendiri seperti yang tercantum di kontrak. Riza Edwindra mempunyai pengalaman kliennya yang "ngambul". "Ngambul" atau merajuk dalam artian klien ini tidak terima akan penjelasan darinya. Namun, ia tetap memberitahu kliennya apa yang kliennya ini lakukan salah. Terlebih lagi ia telah mengetahui bahwa kliennya menyembunyikan omset riilnya. Hal ini menyebabkan kliennya merasa "takut" akan resiko dan lebih memilih aman dengan mengikuti sesuai aturan.

Konsultan pajak melakukan suatu pertimbangan untuk menghindarinya dari suatu dilema. Salah satu pertimbangan yang dilakukan adalah dengan memilih suatu cara yang tepat untuk menghilangkan dilema yang dirasakan. Melalui pernyataan yang diungkapkan oleh konsultan pajak tersebut dapat ditarik kesimpulan bahwa cara konsultan pajak dalam menghilangkan rasa dilemanya adalah dengan membuat suatu tujuan yaitu membangun kesadaran wajib pajak. Membangun kesadaran wajib pajak dilakukan dengan mengikuti keinginan wajib pajak terlebih dahulu, mendengarkan dan memahami wajib pajak, setelah itu sedikit demi sedikit dijelaskan mengenai kewajiban perpajakan secara benar. Seperti yang diungkapkan konsultan pajak Kadek Agus berikut ini:

"kalo bahasanya gini gek, kalo gek mau curhat, kan kita dengerin dulu, kita dengerin dulu klien ngomong apa, kita dukung dulu klien mau apa, nanti dikit-dikit halusin halusin cerahin eh mau sendiri berubah haha" (Senin, 18 Juni 2018: 13.28 WITA).

Kadek Agus memberikan ungkapan "curhat", dimana ia akan mendengarkan kliennya terlebih dahulu, memahami, mendukung kliennya, nantinya sedikit demi sedikit memberikan "pencerahan" kepada klien. "Pencerahan" diberikan dengan tujuan agar wajib pajak (klien) sadar dengan sendirinya, serta peduli akan pajak dengan sendirinya. Konsultan pajak Kadek Agus menambahkan:

"fenomena ini banyak terjadi dilapangan dan gak bisa dipungkiri gek... cara mengatasi dilema ini ya pahami dulu situasinya..." (Senin, 18 Juni 2018: 13.28 WITA). 
Pernyataan konsultan pajak Kadek Agus mengindikasikan bahwa fenomena dilema akan membuat suatu keputusan banyak terjadi saat konsultan pajak melakukan tugasnya. Cara mengatasinya dengan dipahami terlebih dahulu situasi seperti apa, apa yang terjadi sesungguhnya terhadap klien, sehingga dapat ditemukan cara untuk membangun kesadaran dari klien tersebut.

Melalui pernyataan dari pengalaman yang diungkapkan oleh konsultan pajak tersebut, dapat dipahami bahwa suatu dilema dalam penerapan tax planning dapat diminimalisir dengan membangun kesadaran wajib pajak. Konsultan pajak dalam menerapkan tax planning diperlukan data yang riil agar tidak terjadi resiko saat dilakukannya pemeriksaan. Namun, terkadang wajib pajak menyembunyikan data riilnya dari konsultan pajak dengan berbagai macam alasan guna untuk menarik rasa simpati konsultan pajak. Hal ini menyebabkan dilema, disatu sisi konsultan pajak mengetahui bahwa data yang diberikan oleh kliennya tidak riil. Disisi lain, konsultan pajak memahami alasan yang menyebabkan klien melakukan hal tersebut.

Dilema ini dapat diatasi dengan memahami situasi terlebih dahulu, mengatur "siasat" untuk membangun kesadaran wajib pajak. "Siasat" yang dimaksud adalah konsultan pajak tetap mengikuti keinginan klien, namun dengan menggunakan cara halus dalam memberikan pemahaman tentang perpajakan, konsultan pajak dapat sedikit demi sedikit membangun rasa kepedulian wajib pajak terhadap perpajakan dan kesadaran akan patuh pun dapat muncul. Wajib pajak yang sadar pun mulai memberikan data secara riil, membayar pajak sesuai dengan kewajibannya, sehingga dilema konsultan pajak pun dapat dihilangkan.

\section{Kesimpulan}

Simpulan yang dapat diperoleh dari penelitian ini adalah konsultan pajak dalam melakukan tax planning selalu diliputi rasa dilema, namun konsultan pajak tetap mencari cara untuk mengatasi dilema yang dirasakan. Dilema yang muncul akibat dari beberapa faktor seperti dilema yang muncul akibat adanya peraturan yang masih "abu-abu". Membuat tax planning yang masih dalam lingkup peraturan (legal) menggunakan celah yang dikatakan "area abu-abu" dalam suatu peraturan. Namun terkadang area tersebut dapat memicu perbedaan penafsiran antara petugas pajak dengan dirinya. Hal ini menyebabkan konsultan pajak merasa dilema serta khawatir dalam menentukan celah apa yang akan digunakan, apakah beresiko atau tidak.

Faktor lainnya yaitu konsultan pajak memiliki rasa simpati terhadap kliennya. Klien kerap menyembunyikan omset sesungguhnya dari konsultan pajak dengan berbagai macam alasan dengan tujuan untuk menarik rasa simpati konsultan pajak. Disatu sisi konsultan pajak mengetahui bahwa klien menyembunyikan omset dan hal tersebut merupakan suatu perbuatan yang menyimpang. Namun disisi lain, konsultan pajak merasa kasihan terhadap klien. Hal ini pun juga menyebabkan konsultan pajak merasa dilema.

Dilema yang dirasakan membuat konsultan pajak mencari cara untuk menghilangkannya. Siapapun tidak ingin merasakan dilema berkepanjangan. Konsultan pajak pun demikian. Konsultan pajak mengatasi dilema dalam berbagai macam pertimbangan seperti, sebagai konsultan pajak menyadari bahwa memahami secara baik peraturan merupakan sesuatu yang sangat penting. Maka dari itu, untuk menghindarinya dari rasa dilema konsultan pajak harus mendalami peraturan-peraturan sehingga konsultan pajak akan secara mudah untuk melakukan pemilihan celah dalam yang akan digunakannya untuk tax planning.

Konsultan pajak harus memahami celah yang digunakannya, menganalisis celah, memprediksikan apa yang akan terjadi jika celah tersebut menimbulkan suatu masalah. Pemahaman akan peraturan tersebut akan membuat konsultan pajak merasa yakin atas celah yang akan digunakan untuk membuat tax planning sehingga dilema yang dirasakan dapat diminimalisir. Selain memahami peraturan, dilema dapat diatasi dengan membangun rasa kepatuhan wajib pajak. Wajib pajak terkadang saat melakukan tax planning menyembunyikan omset sesungguhnya dari konsultan pajak dengan berbagai macam alasan. Konsultan pajak mengetahui hal tersebut salah, namun konsultan pajak memiliki rasa simpati. Maka dari itu, untuk menghindarinya dari rasa dilema, konsultan pajak memikirkan untuk membuat suatu "siasat".

Konsultan pajak akan mendengarkan, mengikuti keinginan klien terlebih dahulu. Sembari demikian konsultan pajak memberikan pemahaman secara halus, sedikit demi sedikit. Lambat laun klien akan sadar dengan sendirinya, dan perlahan membuka omset riilnya. Adanya kesadaran klien tersebut, membuat dilema yang dirasakan konsultan pajak menjadi menghilang. Sebab, sejalan dengan klien memberikan data riil, konsultan pajak pun tidak merasakan dilema.

Berdasarkan hasil penelitian ini membuahkan saran untuk peneltian selanjutnya. Penelitian tentang pengalaman konsultan pajak sangat jarang dilakukan. Peneliti berharap dengan adanya penelitian ini dapat membangun sebuah ide untuk membuat penelitian selanjutnya tentang konsultan pajak dengan menggunakan studi lainnya ataupun menambah jumlah informan sehingga mendapatkan hasil yang lebih beragam. 


\section{Daftar Pustaka}

Auliyana, E. (2017). Studi Kasus Fenomenologi Atas Opini Audit WTP di Kalangan Pejabat Pemerintah Provinsi Jawa Timur. Jurnal Akuntansi Aktual, Vol 4, No 1, pp. 22-33.

Bertens, K. (2000). Pengantar Etika Bisnis. Yogyakarta: Kanisius.

Creswell, J. (2007). Qualitative Inquiry \& Research Design: Choosing Among Five Approaches, 2nd ed. California: Sage Publication.

Creswell, J. W. (2016). Penelitian Kualitatif \& Desain Riset: Memilih Diantara Lima Pendekatan Edisi Lima. Yogyakarta: Pustaka Belajar.

Darmayasa, \& Hardika. (2011). Perencanaan Pajak Dari Aspek Ratio Total Benchmarking Kebijakan Akuntansi, Dan Administrasi Sebagai Strategi Penghematan Pajak. Jurnal Bisnis Dan Kewirausahaan, Vol 7 No 3 , pp.162-169.

Devos, K. (2012). The Impact of Tax Professionals Upon the Compliance Behavior of Australian Individual Taxpayers Revenue. Law Journal, Volo. 22 (1), pp.1-26.

Erard, B.( 1993). Taxation with Representation: An Analysis of The Role of Tax Practitioners in Tax Compliance. Journal of Public Economics, Vol. 52(2), pp.163- 197.

Fitriani, E, I. (2014). Makna Harga Diri Pada Remaja Putri Yang Melakukan Hubungan Seksual Pranikah Di Pekanbaru. Universitas Islam Negeri Sultan Sarif Kasim, Riau.

Frecknall-Hughes, J., \& Kirchler, E. (2015). Towards a General Theory of Tax Practice. Social \& Legal Studies, Vol. 24(2), pp 289- 312.

Giarti. (2012). Pentingnya Kesadaran Wajib Pajak. Bangkapos.com [Internet], 20 April 2012. Dapat diakses pada http://bangka.tribunnews.com/2012/04/20/penting nya-kesadaran-wajib-pajak [Diakses tanggal 17 Juli 2018].

IKPI, Komisi Kode Etik. (2009). AD ART Kode Etik Ikatan Konsultan Pajak Indonesia. Batam: Komisi Kode Etik.

Khoesanto, M, Y. (2013). Pengaruh Karaktristik Eksekutif terhadap Tax Avoidance pada Perusahaan Manufaktur. Skripsi, Universitas Katolik Widya Mandala, Surabaya.

Kuswarno, E. (2009). Meotde Penelitian Komunikasi Fenomenologi. Bandung: Widyapadjajaran.

Mangoting, Y. (2017). Menguak Dimensi Kecurangan Pajak. Jurnal Akuntansi Multiparadigma (JAMAL), Vol. 8(2), pp.227-429.

Massie, J, M. (2017). Pengaruh Etika Profesi, Religiusitas dan Kompetensi Terhadap
Pengambilan Keputusan Etis Konsultan Pajak. Undergraduate Thesis. Universitas Kristen Maranatha, Bandung.

Moleong, L, J. (2017). Metode Penelitian Kualitatif. Bandung: PT Remaja Rosdakarya.

Moustakas, C. (1994). Phenomenological Research Methods. Sage Publication: California.

Noviriani, E. (2015). Studi Fenomenologi Atas Dilema Etis Auditor Internal Pemerintah. Ekuitas: Jurnal Ekonomi dan Keuangan, Volume 19, Nomor 2, pp. $217-240$.

Pengertian Dilema www.kbbi.web.id. (Diakses tanggal 27 Juli 2018)

Pengertian Nasionalisme www.wikipedia.com. (Diakses tanggal 30 Juli 2018)

Putu, W. P. (2009). Konstruksi Gender. Skripsi. Fakultas Psikologi, Universitas Indonesia, Depok.

Setyowati, D. (2018). Sri Mulyani Puas, Penerimaan Pajak 2017 Nyaris 90\% dari Target. Katadata.co.id [Internet], 2 Januari 2018. Dapat diakses pada https://katadata.co.id/berita/2018/01/02/srimulyani-puas-target-penerimaan-pajak-2017tercapai-nyaris-90 [Diakses tanggal 3 Maret 2018].

Suardika. (2010). Desain Pembelajaran dengan Pendekatan Siklus Belajar (Learning Cycle). Dapat diakses pada https://aritmaxx.wordpress.com/2010/04/12/disain pembelajarandengan-pendekatan-siklus-belajarlearning-cycle/ [Diakses tanggal 10 Februari 2018].

Undang-Undang No.6 Tahun 1983 jo. Undang-Undang No.28 Tahun 2007 tentang Ketentuan Umum dan Tata Cara Perpajakan. 